\title{
Beak deviations in the skull of Franciscana dolphins Pontoporia blainvillei from Argentina
}

\author{
Pablo Denuncioo ${ }^{1,2, *}$, M. Victoria Panebianco ${ }^{2,3}$, Daniela Del Castillo ${ }^{2,3}$, \\ Diego Rodríguez ${ }^{1,2}$, H. Luis Cappozzo ${ }^{2,3,4}$, Ricardo Bastida ${ }^{1,2}$ \\ ${ }^{1}$ Instituto de Investigaciones Marinas y Costeras (IIMYC), Departamento de Ciencias Marinas, \\ Facultad de Ciencias Exactas y Naturales, Universidad Nacional de Mar del Plata - CONICET, Funes 3350, \\ B7602AYL Mar del Plata, Argentina \\ ${ }^{2}$ Consejo Nacional de Investigaciones Científicas y Técnicas (CONICET), C1429DDA Buenos Aires, Argentina \\ ${ }^{3}$ Laboratorio de Ecología, Comportamiento y Mamíferos Marinos, \\ Museo Argentino de Ciencias Naturales Bernardino Rivadavia (MACN), Av. Ángel Gallardo 470, C1405DJR Buenos Aires, \\ Argentina \\ ${ }^{4}$ Centro de Estudios Biomédicos, Biotecnológicos, Ambientales y Diagnósticos (CEBBAD), \\ Fundación de Historia Natural Félix de Azara, Departamento de Ciencias Naturales y Antropología, Universidad Maimó- \\ nides; Hidalgo 775, piso 7, C1405BDB Buenos Aires, Argentina
}

\begin{abstract}
The Franciscana dolphin Pontoporia blainvillei is characterized by a long rostrum, a feature that is shared with the families formerly classified as river dolphins (Pontoporiidae, Platanistidae, Iniidae, Lipotidae). Although there are occasional reports on the existence of beak deformations, very little published information exists describing this process. The object of the present study was to describe and quantify the beak anomalies of Franciscana dolphins from the coastal waters of Argentina. Of 239 skulls analyzed $12 \%$ showed beak deviations (BD), affecting the premaxillary-maxillary and dentary bones to different extents. The occurrence of BD in the dentary bone represented $58 \%$, whereas premaxillary-maxillary BDs were observed in $14 \%$ of the studied specimens, while the complete rostrum (dentary, premaxillary and maxillary) was affected in $28 \%$ of the skulls. Dorsoventral axis BD was more frequent than lateral BD (48 and $38 \%$, respectively), and double BD was only observed in the dentary bone. Most of the BD observed in this study could be classified as mild/moderate, and we assume that it did not affect the feeding activities of individuals; however, 2 specimens $(<1 \%)$ showed a severe and complex curvature that probably did affect them. The cause of these anomalies (natural or anthropogenic origins) is unknown but may be related to important parasite loads, heavy metal and organic contaminants and plastic ingestion that could affect the coastal dolphin in different ways. A more detailed and thorough study of these cranial anomalies is necessary.
\end{abstract}

KEY WORDS: Franciscana dolphin $\cdot$ Pontoporia blainvillei $\cdot$ Cetacean $\cdot$ Skull anomalies $\cdot$ Rostral bones deviations

Resale or republication not permitted without written consent of the publisher

\section{INTRODUCTION}

The Franciscana dolphin Pontoporia blainvillei is a small cetacean endemic to the southwestern Atlantic Ocean, ranging from Itaúnas $\left(18^{\circ} 25^{\prime} \mathrm{S}, 30^{\circ} 42^{\prime} \mathrm{W}\right.$, Brazil) to Golfo Nuevo ( $42^{\circ} 35^{\prime} \mathrm{S}, 64^{\circ} 48^{\prime} \mathrm{W}$, Argentina) (Siciliano 1994, Crespo et al. 1998, Bastida et al.
2007). Its distribution is restricted to coastal waters up to $30 \mathrm{~m}$ depth (Pinedo et al. 1989, Danilewicz et al. 2009), which makes it vulnerable to anthropogenic activities (Ott et al. 2002 and references therein). Between 2000 and 3000 Franciscana dolphins are incidentally caught each year (Cappozzo et al. 2007, Negri et al. 2012), which is the main reason for clas- 
sifying this species as 'Vulnerable' along its whole distribution (Reeves et al. 2012).

Though incidental captures represent the main threat to the species, little is known about their diseases and natural mortality (Danilewicz et al. 2002). Even less is known about skeletal and skull diseases and/or anomalies. Skull diseases of Franciscana dolphins have briefly been reported by Gerholdt (2006), with rostral anomalies observed in one specimen. Grey literature mentions several cases of anomalies in the skull of Franciscana dolphins - from Brazil and Argentina - but does not discuss possible implications for the health and survival of the affected specimens (Ott et al. 1996, Junín et al. 1997).

Some osteological anomalies (i.e. vertebral anomalies) result from degenerative processes associated with aging (Kompanje 1995), whereas others result from pathological or unknown origin and may affect young individuals, resulting in severe functional limitations or even death at pre-reproductive stages (Félix et al. 2007). Anomalies of the rostral bones could affect and interfere with feeding mechanisms or trophic strategies and could have consequences for the survival of individuals. The objective of the present study was to quantify and describe the presence of beak deviations affecting the skulls of Franciscanas in the coastal waters of Argentina.

\section{MATERIALS AND METHODS}

A total of 239 skulls of Franciscanas accidentally captured or stranded along the coasts of the Buenos Aires Province were studied. Skull samples from the Marine Mammal Laboratories of the Museo Argentino de Ciencias Naturales 'Bernardino Rivadavia' (MACN) and the Universidad Nacional de Mar del Plata (UNMDP), Argentina, were studied.

Crania and mandibles of each specimen were examined, and beak deviations (BD) were recorded and classified by bones affected (premaxillary, maxillary and dentary), axis of the deviation (dorsoventral and lateral) and type of anomaly (anomalies with single or double curvature; see Figs. 1B,C). Skulls were also classified on the basis of the degree of beak deviation (moderate or severe), taking into account whether bone malformation affects the normal use of jaws during its feeding activities. Additional information about sex, standard length (SL) and stranding or capture localities of the specimens were also recorded (see Table 1).

Data was expressed in relative frequency of occurrence $(\mathrm{FO} \%)$, defined as the number of times a mal- formation occurs in the total of specimens analyzed. Log-linear analysis of associations between frequency of malformation related to sex and age class were used. Age classes were defined as newborn/calves to specimens up to $100 \mathrm{~cm}$ and juvenile/adults to specimens >100 cm SL (Rodríguez et al. 2002, Denuncio et al. 2013).

\section{RESULTS}

A total of 239 skulls were analyzed of which $12 \%$ ( $\mathrm{n}=29$ ) showed BDs. Such BDs involved bones of both the cranium (premaxillary and maxillary) and/ or the mandible (dentary bone) in different ratios and combinations (Table 1).

For a better understanding of each deviation, a basic control skull has been included in the Figs. 1A $\& 2 \mathrm{~A}, \mathrm{C}$. The BD of the dentary bone (Fig. 1) was the most frequent malformation (58\% of total instances), accompanied by the abnormal curve of the premaxillary-maxillary bones of the skull (14\%; Fig. 2). The presence of BD in both the upper and lower jaws was observed in $28 \%$ of the affected specimens (Fig. 3). In all cases, the same axis deviation (lateral, dorsoventral, or both) was found in the premaxillarymaxillary and dentary.

Dorsoventral BD accounted for $48.2 \%$ of all anomalies (Fig. 2B), whereas the lateral axis anomalies accounted only for $41.3 \%$ (Fig. 2D). Left side curvatures were more frequent than to the right side (8 vs. 3). Complex anomalies (showing both types of deviations) were found in $10.5 \%$ of total anomalies (Fig. 3). Moreover, malformations showed both a single curvature (Fig. 1B) and double curvature (Fig. 1C), with a clear dominance of the single ones (71\%). Double curvatures were not found in lateral axis deviations.

All dolphins died entangled in gill nets and were in good body condition. Log-linear models revealed a significant effect of sex, with males having a significantly higher prevalence of BD than females (Table 2). Age class did not significantly affect prevalence (Table 2). The presence of BD was independent of the bone affected $\left(\chi^{2}=1.24 ; \mathrm{df}=2 ; \mathrm{p}=0.536\right)$.

\section{DISCUSSION}

Several studies have reported the presence of bone diseases and traumata in cetaceans worldwide (i.e. Lambertsen 1992, McFee et al. 1997, Pascual et al. 2000, Van Bressem et al. 2006, 2009). Van Bressem et al. (2007) reviewed the external affections of ceta- 
Table 1. Description of anomalous skull of Pontoporia blainvillei from Argentina. MACN: Museo Argentino de Ciencias Naturales; UNMDP: Universidad Nacional de Mar del Plata; TL: total length; Dors.: dorsal; Vent.: ventral; M: male; F: female. nd: no data; -: not present

\begin{tabular}{|c|c|c|c|c|c|c|c|c|c|c|}
\hline \multirow[t]{3}{*}{ Collectior } & \multirow[t]{3}{*}{ ID } & \multirow{3}{*}{$\begin{array}{c}\text { Date of } \\
\text { stranded or } \\
\text { by caught }\end{array}$} & \multirow[t]{3}{*}{ Sex } & \multirow{3}{*}{$\begin{array}{l}\text { Age } \\
(y r)\end{array}$} & \multirow{3}{*}{$\begin{array}{c}\mathrm{TL} \\
(\mathrm{cm})\end{array}$} & \multirow[t]{3}{*}{ Locality } & \multicolumn{4}{|c|}{ - Malformed bones } \\
\hline & & & & & & & - Dent & & Premaxillary & Maxilary \\
\hline & & & & & & & Axis & Type & Axis & Type \\
\hline MACN & N-04-04 / 25456 & 21 Sep 2004 & $\mathrm{~F}$ & 1 & 112.5 & Necochea & Dors.-Vent. & Double & Dors.-Vent. & Simple \\
\hline MACN & CL-09-02/26036 & 27 Feb 2009 & $\mathrm{~F}$ & 4 & 142.0 & Claromecó & Lateral & Simple & - & - \\
\hline MACN & MH-11-02 & 1 Jan 2011 & F & 4 & 144.5 & Monte Hermoso & Lateral & Simple & - & - \\
\hline MACN & N-98-07 / 25448 & 1998 & F & 4 & 158.5 & Necochea & Both & Simple & Both & Simple \\
\hline $\mathrm{MACN}$ & MH-04-01 & 1 May 2004 & $\mathrm{M}$ & 1 & 98.3 & Monte Hermoso & Dors.-Vent. & Double & - & - \\
\hline $\mathrm{MACN}$ & N-04-06 / 25455 & 15 Sep 2004 & $\mathrm{M}$ & 2 & 112.0 & Necochea & Lateral & Simple & - & - \\
\hline $\mathrm{MACN}$ & BB-09-01/26032 & 1 Sep 2005 & $\mathrm{M}$ & 7 & 127.5 & Bahía Blanca & Lateral & Simple & - & - \\
\hline MACN & BB-03-02/26031 & 1 Dec 2009 & $\mathrm{M}$ & 8 & 135.0 & Bahía Blanca & Dors.-Vent. & Simple & Dors.-Vent. & Simple \\
\hline $\mathrm{MACN}$ & N-04-01 / 24827 & 1 Aug 2004 & $\mathrm{M}$ & 13 & 141.5 & Necochea & Dors.-Vent. & Simple & Dors.-Vent. & Simple \\
\hline $\mathrm{MACN}$ & N-90-05 / 25459 & 1990 & nd & nd & nd & Unknown & Dors.-Vent. & Simple & - & - \\
\hline MACN & N-89-21 / 25469 & 1989 & nd & nd & nd & Unknown & Lateral & Simple & - & - \\
\hline MACN & 25313 & nd & nd & nd & nd & Unknown & Lateral & Simple & - & - \\
\hline $\mathrm{MACN}$ & $25.167^{\mathrm{a}}$ & nd & nd & nd & nd & Mar del Plata & - & - & Lateral & Simple \\
\hline MACN & 27.39 & Feb 1997 & nd & nd & nd & Necochea/Claromecó & Lateral & Simple & - & - \\
\hline UNMDP & $\mathrm{Pb} 1808$ & 3 Aug 2008 & $\mathrm{~F}$ & 1 & 119.0 & Claromecó & - & - & Dors.-Vent. & Simple \\
\hline UNMDP & $\mathrm{Pb} 2108$ & 8 Nov 2008 & $\mathrm{~F}$ & 5 & 150.0 & Claromecó & Lateral & Simple & - & - \\
\hline UNMDP & AH10 & 5 Dec 1997 & $\mathrm{~F}$ & & 54.4 & San Clemente & Both & Simple & Both & Double \\
\hline UNMDP & AH26 & 12 Jan 1996 & $\mathrm{~F}$ & & 107.5 & Samborombón & - & - & Dors.-Vent. & Simple \\
\hline UNMDP & $\mathrm{Pb} 7010$ & 6 Mar 2010 & $\mathrm{M}$ & 0 & 81.0 & Río Salado & Dors.-Vent. & Double & - & - \\
\hline UNMDP & $\mathrm{Pb} 2708$ & 4 Dec 2008 & $\mathrm{M}$ & 1 & 105.0 & Necochea & - & - & Dors.-Vent. & Simple \\
\hline UNMDP & $\mathrm{Pb} 0808$ & 23 Feb 2008 & $\mathrm{M}$ & 3 & 129.0 & Claromecó & Dors.-Vent. & Simple & Dors.-Vent. & Simple \\
\hline UNMDP & Pb3409 & 10 Jan 2009 & M & 5 & 136.0 & Nueva Atlantis & Both & Simple & Both & Simple \\
\hline UNMDP & AH08 & 13 Jan 1998 & $\mathrm{M}$ & nd & 119.0 & Samborombón & Dors.-Vent. & Simple & - & - \\
\hline UNMDP & AH17 & 7 Jan 1998 & $\mathrm{M}$ & nd & 115.4 & Samborombón & Lateral & Simple & - & - \\
\hline UNMDP & AH31 & 18 Mar 1998 & $\mathrm{M}$ & nd & 151.0 & Pinamar & Lateral & Simple & - & - \\
\hline UNMDP & $\mathrm{AH} 03$ & 18 Mar 1998 & nd & nd & 107.0 & Pinamar & Lateral & Simple & Lateral & Simple \\
\hline UNMDP & AH05 & 18 Mar 1998 & nd & nd & 115.0 & Punta Médanos & Dors.-Vent. & Double & - & - \\
\hline UNMDP & AH19 & 25 Jun 1995 & nd & nd & 115.0 & San Clemente & Dors.-Vent. & Simple & - & - \\
\hline UNMDP & AH32 & 9 Jan 1996 & nd & nd & 136.0 & Chapadmalal & Dors.-Vent. & Simple & - & - \\
\hline
\end{tabular}

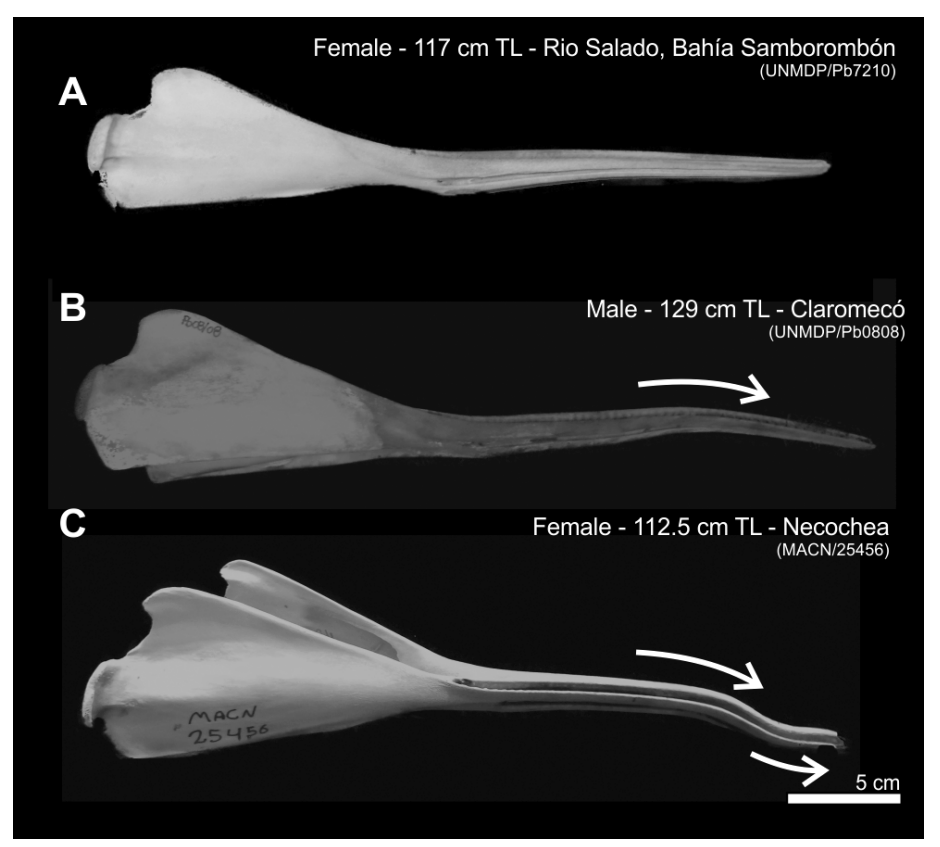

ceans from South American waters (mainly from Brazil and Peru), as well as cutaneous diseases (tattoo skin diseases, whitish velvety lesions, lobomycosis-like diseases and rounded cutaneous lesions) and internal affections such as skeletal lesions (fractures or trauma, osteomyelitis, osteolysis, crassicauda-related, malformations, etc.). Dental pathologies were also recorded in cetaceans (Loch et al. 2011). Some of the most common skeletal affections recorded in cetaceans are incomplete closed vertebral arches (Laeta et al. 2010), vertebral ankylosis (DeLynn et al. 2011, Fettuccia et al. 2013), spondylitis (Van Bressem et al. 2007,

Fig. 1. Mandibular deviations in the skull of Pontoporia blainvillei from Argentina: (A) basic control mandible; (B) abnormal mandibular bone deviation with single curvature; and (C) abnormal mandible deviation with double curvature. TL: total length 
Fig. 2. Premaxillary-maxillary deviations in the skull of Pontoporia blainvillei from Argentina: lateral view of (A) basic control skull, (B) dorsoventral axis curvature, and dorsoventral view of (C) basic control skull and (D) lateral axis deviation. TL: total length

Fettuccia et al. 2013), anomalous curvature of the spinous processes (DeLynn et al. 2011), brachygnathia and prognatism (Van Bressem et al. 2007), beak deviations (Montes et al. 2004, Van Bressem et al. 2006) and fractures and other traumata (Montes et al. 2004, Van Bressem et al. 2006, 2007, Sanfelice \& Ferigolo 2012).

The only skull anomalies in Franciscana dolphins previously reported (Ott et al. 1996, Junín et al. 1997, Gerholdt 2006) seem to affect the rostral bones. Ott et al. (1996) found that $<1 \%$ of the skull analyzed showed BDs in southern Brazil specimens, whereas Junín et al. (1997) reported a higher percentage of BDs in Franciscanas (24\%) from Argentina, with the caveat that the sample size was small $(\mathrm{n}=25)$. Our study reveals that $12 \%$ of 239 skulls showed such anomalies affecting both upper and lower jaws in different axes

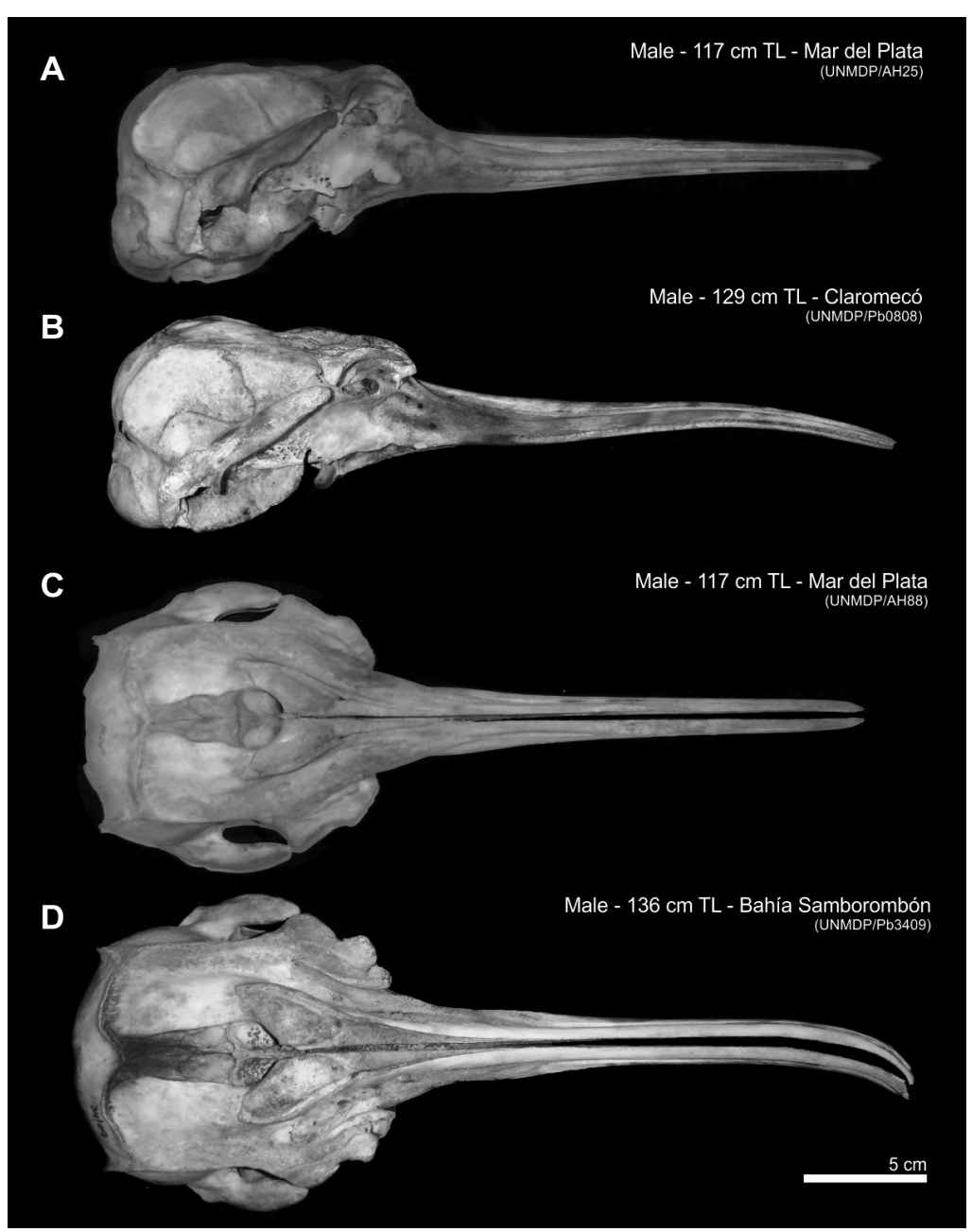

of deviations, bones affected and degrees of abnormality.

The rostrum is the region that showed all macroscopic malformations. These rostral deviations were classified in the lateral axis, the dorsoventral axis and in a complex, i.e. including both directions. The most common was the dorsoventral, with moderate curvatures mainly of the dentary bone. Such a description has not been given in other Francis-

Fig. 3. Complex and severe beak deviations in the skull of Pontoporia blainvillei from Argentina, showing dorsoventral and lateral deviations. (A) Dorsal and (B \& C) lateral views of the skull of a newborn specimen. (D) Lateral view and (E) zoom detail of the tip of the rostrum in a $5 \mathrm{yr}$ old specimen. TL: total length 
Table 2. Associations (likelihood ratio) between malformation, sex and standard length (SL). Statistical tests used were from a hierarchical log-linear analysis of a contingency table of malformation (2 levels: yes and no), sex (2 levels: males and females) and SL (2 levels: newborn/calves and juvenile adults)

\begin{tabular}{|lcrr|}
\hline Effect & df & $\chi^{2}$ & \multicolumn{1}{c|}{$\mathrm{p}$} \\
\hline Malformation-Sex & 4 & 46.219 & $<0.001$ \\
Malformation-SL & 4 & 5.349 & 0.253 \\
\hline
\end{tabular}

cana studies; however, illustrations in the articles published by Junín et al. (1997) and Gerholdt (2006) allow us to see dorsoventral, lateral and complex beak deviations in the species. Few examples have been published for other cetaceans. Van Bressem et al. (2006) and Montes et al. (2004) showed a dorsoventral deviation in a long-beaked common dolphin Delphinus capensis.

Ferigolo (1987) suggested that anatomical malformation is not always synonymous with pathology; however, it is difficult to determine whether such variation reflects cases of congenital malformation or is part of normal intraspecific morphological variation. The Franciscana rostrum is extremely long and slender (Reeves et al. 2002), and it is in the rostral region of the skull where most ontogenetic changes are observed (Negri et al. 2009, Bastida 2010, Del Castillo et al. 2014), increasing from $<10$ to $15 \%$ of the relative standard length of the animal (Reeves et al. 2002). Gerholdt (2006) suggested that this delicate and long beak is more susceptible to fracture and disturbance than the more robust beaks in other cetaceans. In this sense, only one of the specimens analyzed in the present study showed a beak deviation as a consequence of fracture (callus formation, MACN25167; Junín et al. 1997). However, a high number of complete beak fractures were observed (not included in the present study), probably related to entanglement in fishing nets.

Franciscana dolphins are accidentally captured by gill nets throughout their geographical distribution (Ott et al. 2002, Negri et al. 2012), and, despite the fact that it is difficult to associate beak deviations with netting, this small cetacean is generally entangled by its pectoral flukes and beak. Thus, this kind of anthropogenic activity may influence the course of disease, as well as damage, caused directly by trauma and injuries. Therefore, we cannot disregard the possibility that in such situations minor trauma may take place affecting ossification centers and, subsequently, abnormal bone development during the individual's growth. Our study reported the presence of BD from newborn to adult dolphins, and no mechanical interference in the mouth opening was clearly visible. Based on this, we suggest that these anomalies might not affect the feeding ecology of the species, especially, if we consider that Franciscana dolphins feed on small prey (fish and cephalopods of 55 and $106.1 \mathrm{~mm}$ modal size; Denuncio 2012).

Bone anomalies were observed in all age classes and sexes, with severe deviations seen in a newborn female (UNMDP/Ah10) and in a $5 \mathrm{yr}$ old adult male (UNMDP/Pb3409) (Fig. 3). However, males were more significantly affected by rostral deviations than females. Possible sexual fights between males might explain a higher prevalence of beak malformations in males. Nevertheless, aggression between males has not been observed (Danilewicz et al. 2004, Panebianco et al. 2012a), and fresh and old tooth rakes have not been recorded for the species.

Marine mammals accumulate heavy metals in their tissues at different concentrations according to their trophic level and environmental conditions (Gerpe et al. 2002). They could suffer malformations due to the effect of these substances that are absorbed by their bodies when feeding (Watson \& Bonde 1986, Weinstein 1995, Berghan \& Visser 2000, Siciliano et al. 2005). Some of these contaminants, such as cadmium, may have an effect on the development of bone tissue in various vertebrate groups, or they may have mutagenic effects (Pragatheeswaran et al. 1987, Wang \& Bhattacharyya 1993, Filipic et al. 2006).

Franciscana dolphins accumulate heavy metals in their tissues during their ontogeny (Gerpe et al. 2002). The latest studies of the effect of pollution on Franciscanas, carried out in Argentina, describe the presence of several heavy metals such as $\mathrm{Hg}, \mathrm{Cd}, \mathrm{Cu}$ and Zn (Gerpe et al. 2002, Panebianco et al. 2011, 2012b, 2013, Polizzi et al. 2013) and variable metallothionein concentrations (low-molecular weight protein biomarkers of chemical stress) (Polizzi et al. 2014). However, the authors suggest that these results correspond to the levels of healthy organisms with background physiological values. However, we cannot rule out that these heavy metals or other contaminants not measured in these studies (e.g. organic contaminants) affect this small dolphin and could explain the cases of malformation recorded in the present study. Plastic ingestion has also been registered in the stomach contents of this species (Denuncio et al. 2011), and, despite the mechanical obstruction of the gastrointestinal tract, there are sublethal effects associated with the transfer of per- 
sistent organic pollutants trapped on the surface of plastics (Rios et al. 2007).

Van Bressem et al. (2009) suggest that inshore, estuarine and riverine cetaceans are particularly at risk because coastal and fluvial ecosystems are often dramatically degraded by human activities. However, as stated by Ferigolo (1987), it is hard to conclude whether such anomalies are a consequence of extrinsic or intrinsic factors. This warrants further investigation.

In summary, our study shows that cranial and mandibular deviation in Franciscana dolphins is fairly common and that males have a higher prevalence of BD than females. The vast majority of anomalies did not appear to interfere with jaw movements and foraging abilities. Further research is necessary to understand the process and causes of beak malformation in Franciscanas and to evaluate the impact of malformation on the survival of the affected dolphins.

Acknowledgements. Financial support for this work was provided by Consejo Nacional de Investigaciones Científicas y Técnicas (CONICET) and Cetacean Society International (CSI). We gratefully acknowledge the local fishermen who helped us in the collection of by-caught specimens (2007-2014). Special thanks to Marité from the Coastal Marine Station 'J.J. Nagera' (UNMDP) for her important help during necropsy work and to William Rossiter from CSI for his valuable cooperation. Finally, we thank Mr. Peter Miles for careful review of the manuscript and improvement of our English. This study was conducted as part of the post$\mathrm{PhD}$ research of Pablo Denuncio (Universidad Nacional de Mar del Plata).

\section{LITERATURE CITED}

Bastida J (2010) Crecimiento y desarrollo craneal en delfines del Plata, Pontoporia blainvillei (Gervais y D'Orbigny, 1844). BSc dissertation, Universidad Caece, Buenos Aires

Bastida R, Rodríguez D, Secchi E, da Silva V (2007) Mamíferos Acuáticos de Sudamérica y Antártida. Vázquez Mazzini Editores, Buenos Aires

Berghan J, Visser IN (2000) Vertebral column malformations in New Zeland delphinids with a review of cases worldwide. Aquat Mamm 26:17-25

Cappozzo HL, Negri MF, Pérez FH, Albareda D, Monzón F, Corcuera JF (2007) Incidental mortality of Franciscana dolphin (Pontoporia blainvillei) in Argentina. lat Am J Aquat Mamm 6:127-137

Crespo EA, Harris G, González R (1998) Group size and distributional range of the Franciscana Pontoporia blainvillei. Mar Mamm Sci 14:845-849

Danilewicz D, Claver JA, Carrera ALP, Secchi ER, Fontoura NF (2004) Reproductive biology of male Franciscanas (Pontoporia blainvillei) from Rio Grande do Sul, southern Brazil. Fish Bull 102:581-592
Danilewicz D, Rosas F, Bastida R, Marigo J and others (2002) Report of the Working Group on Biology and Ecology. Lat Am J Aquat Mamm 1:25-42

> Danilewicz D, Secchi ER, Ott PH, Moreno IB, Bassoi M, Borges-Martins M (2009) Habitat use patterns of Franciscana dolphins (Pontoporia blainvillei) off southern Brazil in relation to water depth. J Mar Biol Assoc UK 89: 943-949

> Del Castillo DL, Flores DA, Cappozzo HL (2014) Ontogenetic development and sexual dimorphism of Franciscana dolphin skull: a 3D geometric morphometric approach. J Morphol 275:1366-1375

> DeLynn R, Lovewell G, Wells RS, Early G (2011) Congenital acoliosis of a bottlenose dolphin. J Wildl Dis 47: 979-983

Denuncio P (2012) Biología y conservación del delfín del Plata (Pontoporia blainvillei) en el sector costero bonaerense. PhD dissertation, Universidad Nacional de Mar del Plata

> Denuncio P, Bastida R, Dassis M, Giardino G, Gerpe M, Rodriguez D (2011) Plastic debris ingested by Franciscana dolphins, Pontoporia blainvillei. Mar Pollut Bull 62: 1836-1841

> Denuncio P, Bastida R, Danilewicz D, Morón S, Rodríguez Heredia S, Rodríguez D (2013) Calf chronology of the Franciscana dolphin: birth, lactation and onset of feeding ecology in coastal waters of Argentina. Aquat Mamm 39: 73-80

Félix F, Haase B, Aguirre WE (2007) Spondylitis in a humpback whale (Megaptera novaeangliae) from the southeast Pacific. Dis Aquat Org 75:259-264

Ferigolo J (1987) Anatomía comparada, paleontología e paleopatología de vertebrados. Paula-Coutiana 1: 105-127

Fettuccia D, Da Silva V, Simões-Lopes PC (2013) Osteological alterations in the tucuxi Sotalia fluviatilis (Cetacea, Delphinidae). Iheringia Ser Zool 103:255-259

> Filipic M, Fatur T, Vudrag M (2006) Molecular mechanisms of cadmium induced mutagenicity. Hum Exp Toxicol 25: $67-77$

Gerholdt JM (2006) Abnormalities and pathologies in the snout of the la Plata dolphin. Ecphora 21:1-5. www. calvertmarinemuseum.com/204/The-Ecphora-Newsletter (accessed 3 Jun 2016)

> Gerpe M, Rodríguez D, Moreno V, Bastida R, Moreno JE (2002) Accumulation of heavy metals in the Franciscana (Pontoporia blainvillei) from Buenos Aires Province, Argentina. Lat Am J Aquat Mamm 1:95-106

Junín M, Castello HP, Zapata M (1997) Patología deformante mandibular en Pontoporia blainvillei (Gervais A. Dórbigny, 1844). In: Crespo EA (eds) Report of the $3^{\text {rd }}$ workshop for coordinated research and conservation of the Franciscana dolphins in the Southwestern Atlantic. United Nations Environment Programme/Convention on Migratory Species (UNEP/CMS), Bonn, p 26-29

Kompanje EJO (1995) Differences between spondylosteomyelitis and spondylosis deformans in small odontocetes based on museum material. Aquat Mamm 21:199-203

Laeta M, Souza SMFM, Siciliano S (2010) Anomalias ósseas congênitas em Sotalia guianensis (Mammalia, Cetacea, Delphinidae) da costa centro-norte do estado do Rio de Janeiro. Pesqui Vet Bras 30:484-490

Lambertsen RH (1992) Crassicaudosis: a parasitic disease threatening the health and population recovery of large baleen whales. Rev Sci Tech Off Int 11:1131-1141 
Loch C, Grando LJ, Kieser JA, Simões-Lopes PC (2011) Dental pathology in dolphins (Cetacea: Delphinidae) from the southern coast of Brazil. Dis Aquat Org 94:225-234

McFee W, Root H, Friedman R, Zolman E (1997) A stingray spine in the scapula of a bottlenose dolphin. J Wildl Dis 33:921-924

Montes ID, Chavera CA, van Bresem M, Perales CR, Falcón NP, van Waerebeek K (2004) Descripción y evaluación anatómica de lesiones óseas cráneo-mandibulares en cetáceos odontocetos del Mar Peruano. Rev Investig Vet Perú 15:13-24

Negri MF, Del Castillo D, Denuncio P, Rodríguez D, Cappozzo L (2009) Alometría en la ontogenia de cráneos del delfín Franciscana Pontoporia blainvillei. VII. Jornadas Nacionales de Ciencias del Mar, Bahía Blanca

Negri MF, Denuncio P, Panebianco MV, Cappozzo HL (2012) Bycatch of Franciscana dolphins Pontoporia blainvillei and artisanal fisheries dynamic in the southernmost distribution of the species. Braz J Oceanogr 60:149-158

Ott PH, Martins MB, Danilewivz D, Oliveira LR, Moreno IBA, Caon G (1996) Anomalías cranianas em toninhas, Pontoporia blainvillei, no Sul do Brasil. In: Aguayo A, Yañez J, Vallejos V (eds) Proc 7th Reunión de Especialistas en Mamíferos Acuáticos de América del Sur, Viña del Mar, p 100

Ott PH, Secchi ER, Moreno IB and others (2002) Report of the working group on fishery interactions. Lat Am J Aquat Mamm 1:55-64

Panebianco MV, Negri MF, Botté SE, Marcovecchio JE, Cappozzo HL (2011) Metales pesados en el riñón del delfín Franciscana, Pontoporia blainvillei (Cetacea: Pontoporiidae) y su relación con parámetros biológicos. Lat Am J Aquat Res 39:526-533

Panebianco MV, Negri MF, Cappozzo HL (2012a) Reproductive aspects of Franciscana dolphins (Pontoporia blainvillei) off Argentina. Anim Reprod Sci 131:41-48

Panebianco MV, Botté SE, Negri MF, Marcovecchio JE, Cappozzo HL (2012b) Heavy metals in liver of the Franciscana dolphin (Pontoporia blainvillei) from the southern coast of Buenos Aires Province, Argentina. J Braz Soc Ecotoxicol 7:33-41

Panebianco MV, Negri MF, Botté SE, Marcovecchio JE, Cappozzo HL (2013) Essential and non-essential heavy metals in skin and muscle tissues in Franciscana dolphins (Pontoporia blainvillei) from southern Argentina coast. Chem Ecol 29:511-518

Pascual S, Abollo E, López A (2000) Elemental analysis of cetacean skull lesions associated with nematode infections. Dis Aquat Org 42:71-75

Pinedo MC, Praderi R, Brownell R Jr (1989) Review of the biology and status of the Franciscana Pontoporia blainvillei. In: Perrin WF, Brownell RL Jr, Kaiya Z, Jiankang L (eds) Biology and conservation of the river dolphins. Occasional Paper of the IUCN Species Survival Commission. IUCN Press, Gland, p 46-51

Polizzi PS, Chiodi Boudet L, Romero B, Denuncio P, Rodríguez D, Gerpe M (2013) Fine scale distribution con-

Editorial responsibility: Steven Raverty,

Abbotsford, British Columbia, Canada strains cadmium accumulation rates in two geographical groups of Franciscana dolphin from Argentina. Mar Pollut Bull 72:41-46

Polizzi PS, Chiodi Boudet L, Romero B, Das K, Denuncio P, Rodríguez D, Gerpe M (2014) Metallothioneins pattern during ontogeny of coastal dolphin, Pontoporia blainvillei, from Argentina. Mar Pollut Bull 80:275-281

Pragatheeswaran V, Loganathan B, Natarajan R, Venugopalan VK (1987) Cadmium induced vertebral deformities in an estuarine fish Ambassis commersoni Cuvier. Proc Indiana Acad Sci 96:389-393

Reeves RR, Stewart BS, Clapham PJ, Powell JA, Folkens P (2002) Guide to marine mammals of the world. Knopf, New York, NY

Reeves RR, Dalebout ML, Jefferson TA, Karczmarski L and others (2012) Pontoporia blainvillei. In: IUCN 2010, The IUCN Red List of Threatened Species 2012: e.T17978 A17623386. www.iucnredlist.org/details/17978/0 (accessed 04 June 2016)

Rios LM, Moore C, Jones PR (2007) Persistent organic pollutants carried by synthetic polymers in the ocean environment. Mar Pollut Bull 54:1230-1237

Rodríguez D, Rivero L, Bastida R (2002) Feeding ecology of the Franciscana (Pontoporia blainvillei) in estuarine and marine waters of northern Argentina. Lat Am Aquat Mamm 1:77-94

Siciliano S (1994) Review of small cetaceans and fishery interactions in coastal waters of Brazil. Rep Int Whaling Comm 15:241-250

Siciliano S, Alves VC, Hacon S (2005) Aves e mamíferos marinhos como sentinelas ecológicas de saúde ambiental: uma revisão do conhecimento brasileiro. Cad Saude Colet 13:927-946

Van Bressem MF, van Waerebeek K, Montes D, Kennedy S and others (2006) Diseases, lesions and malformations in the long-beaked common dolphin Delphinus capensis from the Southeast Pacific. Dis Aquat Org 68:149-165

> Van Bressem MF, Van Waerebeek K, Reyes JC and others (2007) A preliminary overview of skin and skeletal diseases and traumata in small cetaceans from South American waters. Lat Am J Aquat Mamm 6:7-42

Van Bressem MF, Raga JA, Di Guardo G, Jepson PD and others (2009) Emerging infectious diseases in cetaceans worldwide and the possible role of environmental stressors. Dis Aquat Org 86:143-157

> Wang C, Bhattacharyya MH (1993) Effects of cadmium on bone calcium and $45 \mathrm{Ca}$ in nonpregnant mice on a calcium-deficient diet: evidence of direct effect of cadmium on bone. Toxicol Appl Pharmacol 120:228-239

> Watson AG, Bonde RK (1986) Congenital malformations of the flipper in three West Indian manatees, Trichechus manatus, and a proposed mechanism for development of ectrodactyly and cleft hand in mammals. Clin Orthop Relat Res 294-301

Weinstein SL (1995) Deformities of the spine. In: Weinstein JN, Rydevik BL, Sonntag VKH (eds) Essentials of the spine. Raven Press, New York, NY, p 195-230

Submitted: December 7, 2015; Accepted: May 1, 2016

Proofs received from author(s): June 6, 2016 